( П. О. Киричок, д.т.н., професор, О. О. Палюх, К.т.н., доцент, КПІ ім. Ігоря Сікорського, Київ, Україна

\title{
ЕКСПЛУАТАЦІЙНІ ДОСЛІДЖЕННЯ ПОКАЗНИКІВ КУТОВОГО ЗСУВУ КЛЕЙОВОЇ ПОЛІМЕРНОЇ ПЛАСТИНИ КОРІНЦЕВОЇ ЧАСТИНИ КНИЖКОВОГО БЛОКУ
}

\begin{abstract}
Величина деформації окремих ділянок корінцевої клейової полімерної пластини в процесі експлуатаційних навантажень при користуванні книжковими блоками, зшитими нитками, залежить не тільки від пружних властивостей матеріалу клейової композиції, його ізотропності, товщини нанесеного шару, але й від кутів перегинань пластини, які сприяють створенню зон змінної концентрації руйнівних напружень внутрішньої структури. Напруження виникають на краях 3'єднань клейової пластини із папером фальців корінців зошитів з однієї сторони та окантовувальним папером з іншої сторони, у вигляді ділянок стискання та розтягування в місцях дискретних перегинань.

Час дії навантажень, на цих ділянках, пропорційно впливає на зменшення пружних властивостей пластини й розвитку явищ залишкової пластичної деформації.
\end{abstract}

Ключові слова: корінець блока; перегинання пластини; клейова композиція; полімерна пластина;

розкривання блока; зусилля розтягування; кутовий зсув.

\section{Постановка проблеми}

В сучасних технологічних процесах виготовлення книжкової продукції, з метою мінімізації витратної частини, наряду із традиційними видами паперу - книжкового, офсетного, крейдованого широкого розповсюдження набули види паперу виготовлені за спрощеними технологіями, такі як пухкі, висококаландровані, легкокрейдовані та ін.

Фізико-механічні характеристики таких паперів частково нижчі ніж дорожчі зразки, але, в основному, забезпечують необхідні експлуатаційні показники міцності, пластичності, стійкості до руйнівних процесів, на межі утворення та збереження колових отворів, під час зшивання книжкових зошитів синтетичними та бавовняними нитками.

Різноманітна кількість складань палітурних ниток залежно від кількості зошитів та обсягів сторінок в них $є$ одним із чинників впливу на геометричні розміри руйнувань отворів в корінцевій частині зошитів під час їх зшивання.

Використання клейових полімерних композицій з високою

(C) $2018 \mathrm{p}$. 
адгезією та високою липкістю для окантовування книжкових блоків, зшитих нитками, забезпечує міцне й еластичне скріплення корінцевої частини сфальцьованих зошитів та дозволяє забезпечити довготривалу експлуатаційну стійкість книжкових блоків виготовлених із різних видів паперу.

Зміна властивостей клейових композицій під час довготривалих дискретних перегинань корінцевої частини книжкових блоків, у процесі читання, призводить до утворення руйнівних дефектів та втрати цілісності окантовувальної клейової пластини, що до моменту повного руйнування в окремих місцях неякісного з'єднання корінця блоку - втрата цілісності не визначається, обмежуючи можливості, на етапах утворення початкових дефектів, застосувати засоби відновлювального ремонту клейової пластини.

Враховуючи експлуатаційні дослідження показників кутового зсуву при перегинаннях клейової полімерної пластини корінцевої частини книжкового блоку, зшитого нитками, виявити особливості у змінах геометричних розмірів корінцевої клейової пластини залежно від кутів перегинання.

Отримані результати проведених досліджень створюють передумови економного використання палітурних клеїв для окантовування книжкових блоків, зшитих нитками та мінімізації впливу факторів втомного руйнування, викликаних проявами незворотних явищ пластичної деформації.

\section{Аналіз попередніх досліджень}

Відомо, що для врахування особливостей технологічного виготовлення книжкової продукції, необхідно враховувати основні види руйнувань книги, що виникають під час довготривалого їх використання [1]. Руйнування корінцевої клейової пластини, утвореної в технологічному процесі окантовування книжкового блоку, є одним із найбільш поширених дефектів використання книжкової продукції під час її довготривалої експлуатації.

Так, С. Ф. Гавенко у своїх працях [2-6] зазначає, що особливості технологічного процесу окантовування книжкових блоків обумовлюють специфічні вимоги до властивостей термоклеїв, що обмежують можливості їх застосування.

Операції нанесення клею, приклеювання окантовувального матеріалу до корінця, загинання й приклеювання його до форзаців, у процесі окантовування, здійснюється протягом технологічно визначеного проміжку часу, під час якого властивості клею (розплаву) повинні залишатися незмінними, інакше, при нанесенні термоклею на поверхню матеріалу чи на корінець блока знижуються його адгезійні властивості та здатність проникати в пори, що сприятиме пришвидшенню втомно-руйнівних експлуатаційних процесів й скороченню періоду використання книжкової продукції.

Для визначення довговічності видань та підвищення їх міцності важливими є дослідження механізму термічної деструкції клеїв. Диференційно-термічний 
аналіз клеїв показує зміну їх молекулярної маси залежно від температури та ступеня деструкції, швидкості процесів руйнування структури полімерів.

Керуючись теоретичними засадами квалілогії книги, а також враховуючи специфіку скріплення книжкового блоку визначено, що конструктивно-технологічні властивості елементів книжкових видань особливо важливі при оцінюванні експлуатаційних показників: довговічності, міцності, читабельності, естетичності зовнішнього та внутрішнього оформлення.

Г. Г. Петріашвілі проведено аналітичні дослідження напружено-деформованого стану міжсторінкової зони клейового з'єднання книжкового блоку, створена математична модель [7, 8], що дозволяє розраховувати напружено-деформований стан клейового з'єднання, утвореного НКС, в процесі експлуатації книги.

Л. Й. Кулик передбачає технологічні варіанти приклеювання окантовувально-каптальної тасьми до поверхні корінцевої частини, утвореної НКС, для підвищення конструктивної та експлуатаційної міцності й забезпечення максимального кута розкривання блока тощо. Встановлено закономірності впливу фізикомеханічних властивостей окантовувальних матеріалів на міцність видань НКС [9].

Воробйов Д. В. зазначає, що для процесів окантовування книжкових блоків, зшитих нитками, підвищення концентрації клею при постійній його витраті дає значний ефект. Дворазове збільшення концентрації забезпечує приріст міцності склеювання зошитів із неклеєних видів паперу для високого друку в 1,5-2,5 рази та в 3,0-4,5 рази у клеєних офсетних паперів. Застосування концентрованого клею, при постійній витраті сухої речовини, забезпечує більшу міцність склеювання зошитів, кращі умови для сушіння корінця, дозволяє економити клей при обробці блоків з неклеєних видів паперу, якщо норму витрати клею встановити з вимоги необхідної міцності склеювання зошитів, відповідно до терміну служби видання [10].

\section{Мета роботи}

Дослідження деформації клейового шару корінцевої частини книжкового блоку, зшитого нитками, впливу кутів перегинань полімерної клейової пластини в процесі експлуатації книжкової продукції, які сприяють створенню зон змінної концентрації руйнівних напружень внутрішньої структури пластини, а також впливу часу дії навантажень на цих ділянках, що пропорційно впливає на зменшення пружних властивостей пластини та розвитку явищ залишкової пластичної деформації.

\section{Результати проведених досліджень}

Відомо, що для технологічно визначеного зносостійкого скріплення корінцевої частини книжкових блоків, зшитих нитками, а також набуття експлуатаційної міцності з'єднання вагому роль відіграють операції нанесення клейових композицій на корінець та наклеювання окантовувальних матеріалів, з метою надання стійкості блоку до кутового зсуву й закріплення стандартизованої 
форми корінцевої частини, утвореної під час підготовки блоків до окантовувальних процесів, що має зберігати незмінний конструктивний вигляд впродовж втомно-руйнівного періоду довготривалого використання.

Зміцнення корінцевої частини книжкових блоків, що складаються із попередньо підібраних та сфальцьованих зошитів, зшитих нитками, за допомогою клейових композицій, дозволяє фізикохімічними засобами утворювати цілісну систему із кількох матеріальних складових таких, як папір книжкового блоку з різноманітними структурними особливостями: палітурні нитки, що у процесі зшивання блоку створюють на поверхні півкруглих фальців зошитів дискретну структуру 3 попереднім натягом, клейові композиції, рецептурний склад яких сприяє адгезійній взаємодії та адгезійній міцності між компонентами з'єднання, а також окантовувальний папір підвищеної міцності та пластичності [11].

Експлуатаційна міцність клейового з'єднання, його надійність та довготривалість залежить від дотримання умов належного контакту між поверхнею Ш-подібного корінця книжкового блоку (субстрату) та клейовою композицією (адгезиву), що наноситься на корінцеву частину блоку й сприятиме міцному зчепленню в зоні контакту поверхонь паперу блоку та окантовувального клею, обумовленому утворенням адгезійного зв'язку за рахунок дії міжмолекулярних сил різнорідних поверхонь.

Створення сприятливих умов технологічного процесу форму- вання когезійної міцності нанесеного шару клейової композиції перетворює шар клею на тонку полімерну пластину, в яку з однієї сторони імплантована просторова сітка із палітурних ниток, за допомогою яких зшивалась корінцева частина книжкового блоку, а з іншої - окантовувальний папір для надання додаткової міцності клейовому з'єднанню.

Формування з початкового технологічного клейового розплаву окантовувальної полімерної плівки супроводжується явищами мікрореологічної адгезії заповнення капілярів, пор, тріщин пористої поверхні паперу книжкових блоків, за рахунок чого збільшується площа контактів клейової композиції із корінцевою частиною блоку, що сприяє зростанню адгезійної міцності.

Для забезпечення сприятливих умов здійснення мікрореологічної адгезії при утворенні окантовувального клейового з'єднання книжкового блоку, формується селективне підбирання в'язкості клею від якої, в значній мірі, залежить міцність цього з'єднання.

Застосування клейових композицій для скріплення книжкових блоків різних форматів, різної товщини, з різноманітними видами паперу має враховувати необхідні особливості нанесення клею, що мають забезпечити високу адгезію до виду паперу блоку. Полімерна плівка, утворена в результаті подальшої полімеризації клею, після нанесення його на корінець та закріплення, має забезпечити відносне видовження при експлуатації виробу менше або таке, що дорівнює відносному видовженню викорис- 
таного в блоці паперу, а також забезпечити значно вищі показники еластичності та міцності на розрив, ніж паперу сфальцьованих корінців зошитів, зшитих нитками.

Необхідно мати на увазі, що експлуатаційні особливості використання книжкової продукції, у якої блоки зшиті нитками й окантовані клейовими композиціями, та які полягають у багаточисельних послідовних дискретних, або випадкових стохастичних перегинаннях корінця блоку при перегортанні сторінок, у зусиллях, в широких межах прикладених до різних місць перегинань корінцевої частини, для досягнення максимального розкриття блоку, наближеного до кутів у $180^{\circ}$, що забезпечує комфортне читання, поступово призводять до руйнування адгезійних зв'язків й поступового погіршення працездатності корінцевої клейової композитної структури.

Враховуючи те, що довготривалі та багаточисельні перегинання корінцевої частини книжкового блоку потребують нанесення не тільки міцної клейової композиції, але й максимально еластичної - вибір клею, для забезпечення достатньої міцності клейового 3'єднання, необхідно здійснювати відповідно призначенню цього з'єднання, з урахуванням максимальної кількості вимог, що пред'являються в процесі виготовлення кожного виду книжкової продукції та подальшої її експлуатаційної довговічності.

На рис. 1 наведено змодельовану Ш-подібну полімерну клейову пластину, утворену під час технологічного процесу окантовування книжкового блоку, зшитого нитками.

Пластина відтворює форму геометричного арочного склепіння корінця розкритої посередині книги, у якої виділені клиновидні ділянки клею, з увігнутими поверхнями в міжкорінцевому просторі зошитів (рис. 1, поз. 1) та місця дискретного перегинання клейової пластини (рис. 1, поз. 2), що разом враховуються як характерні ознаки в дослідженні експлуатаційних особливостей втомного руйнування клейової композиції.

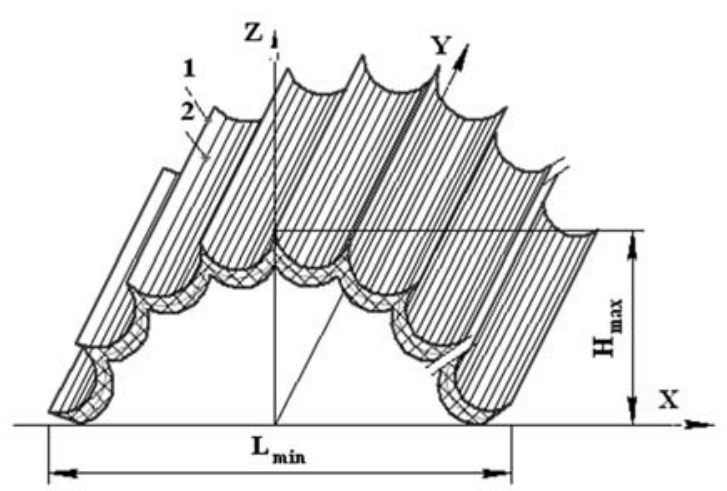

Рис. 1. Дискретне перегинання корінцевої Ш-подібної клейової пластини блока під час читання: 1 - клиновидні ділянки клею з увігнутими поверхнями в міжкорінцевому просторі зошитів; 2 - місця дискретного перегинання клейової пластини 
Під час перегортання сторінок у числовій послідовності, поступово змінюється конфігурація арочного склепіння та змінюється просторова відстань клейової полімерної пластини від першої сторінки до останньої, що до початку перегортання складає L мм (рис. 2, а), а мінімально можлива, при розкриванні блоку посередині, - $L_{\min }$ Mм (рис. 1).

Перегинання пластини від початкової максимальної просторової довжини до мінімальної довжини підстави арочного склепіння фіксується розмірами умовного корінцевого шарніра блоку [1] з визначальним розмірним показником шпації книжкової оправи, яка виготовлена для книжкового блоку.

Висота максимального можливого просторового перегинання клейової пластини $\mathrm{H}_{\max } \mathrm{Mм}$ (вершина правильного арочного склепіння) (рис. 1) на відміну від висоти початкового клейового шару Н мм (рис. 2, а), впро- довж експлуатаційного періоду змінюється в сторону зменшення через поступове втомне руйнування клейової композиції й втрату ознак геометричної подоби арочного склепіння.

Для наочності моделювання кутової деформації полімерної корінцевої пластини книжкового блоку розглянемо кутові переміщення пластини при перегортанні тільки зошитів блоку, зшитого нитками, враховуючи, що для перегортання сторінок блоку, виявлений процес кутової деформації буде тотожнім - лише збільшиться кількість розглядуваних варіантів, що залежатиме від кількості сторінок у блоці.

В першу чергу, кутова деформація - деформація зсуву $\gamma$ полімерної пластини, прикладені зусилля під час послідовновпорядкованого перегортання зошитів й дія, в результаті цього, процесу втомного руйнування пластини в кожній позиції, позначеній на рис. 2, а, як точки а,

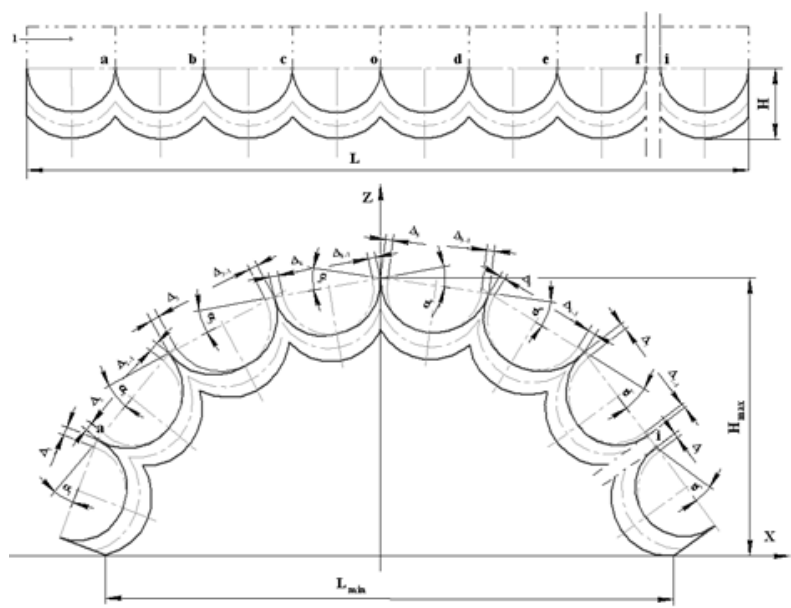

Рис. 2. Зміна геометричних розмірів клейової пластини залежно від кутів перегинання: 1 - фрагменти корінцевої частини сфальцьованих книжкових зошитів 
b, c, o, d...i, залежить від часу знаходження кожної дискретної точки пластини в перегнутому стані під час читання, формуючі різні, за чисельними показниками, руйнівні дефекти:

- при перегинанні полімерної пластини в точці а на кут $\alpha_{1}$ при перегортанні 1-го зошита час знаходження під дією експлуатаційних зусиль складе $\mathrm{t}_{1}=\tau_{1}$;

- при перегинанні полімерної пластини в точці b на кут $\alpha_{2}$ при перегортанні 2-го зошита час знаходження під дією експлуатаційних зусиль складе $t_{1}+t_{2}=$ $=\tau_{2}$;

- при перегинанні ... в точці с на кут $\alpha_{3}$ при перегортанні 3-го зошита час ... складе $\mathrm{t}_{1}+\mathrm{t}_{2}+\mathrm{t}_{3}=$ $=\tau_{3}$;

- при перегинанні ... в точці о на кут $\alpha_{4}$ при перегортанні 4-го зошита час ... складе $\mathrm{t}_{1}+\mathrm{t}_{2}+\mathrm{t}_{3}+$ $+\mathrm{t}_{4}=\tau_{4}$

— при перегинанні ... в точці і на кут $\alpha_{i}$ при перегортанні і-го зошита час ... складе $\mathrm{t}_{1}+\mathrm{t}_{2}+\mathrm{t}_{3}+$ $+\mathrm{t}_{4}+\ldots+\mathrm{t}_{\mathrm{i}}=\tau_{\mathrm{i}}$ де $\mathrm{t}_{1}=\mathrm{t}_{2}=\mathrm{t}_{3}=\mathrm{t}_{4}=\ldots=\mathrm{t}_{\mathrm{j}}$ при однаковому темпі читання й рівномірності перегортання зошитів; $\mathrm{t}_{1} \neq \mathrm{t}_{2} \neq \mathrm{t}_{3} \neq \mathrm{t}_{4} \neq \ldots \neq \mathrm{t}_{\mathrm{i}}$ при нерівномірному перегортанні зошитів в стохастичній послідовності.

Отже, частково, деформацію $\gamma$ кутового зсуву корінцевої клейової полімерної пластини в місцях експлуатаційних дискретних перегинань, можливо представити, як функцію від часу у вигляді:

$$
\begin{aligned}
& -\gamma_{1}=f^{\prime}\left(t_{1}\right)=f^{\prime}\left(\tau_{1}\right) ; \\
& \gamma_{1}=f^{\prime}\left(\tau_{1}\right) ; \\
& -\gamma_{2}=f^{\prime}\left(t_{1}+t_{2}\right)=f^{\prime}\left(\tau_{2}\right) ; \\
& \gamma_{2}=f^{\prime}\left(\tau_{2}\right) ; \\
& -\gamma_{3}=f^{\prime}\left(t_{1}+t_{2}+t_{3}\right)=f^{\prime}\left(\tau_{3}\right) ; \\
& \gamma_{3}=f^{\prime}\left(\tau_{3}\right) ;
\end{aligned}
$$

$$
\begin{aligned}
& -\gamma_{4}=f^{\prime}\left(t_{1}+t_{2}+t_{3}+t_{4}\right)=f^{\prime}\left(\tau_{4}\right) ; \\
& \gamma_{4}=f^{\prime}\left(\tau_{4}\right) ; \\
& -\gamma_{i}=f^{\prime}\left(t_{1}+t_{2}+t_{3}+t_{4}+\ldots+t_{i}\right)= \\
& =f^{\prime}\left(\tau_{i}\right) ; \\
& \gamma_{i}=f^{\prime}\left(\tau_{i}\right) . \\
& \text { Відомо, що кутова деформа- }
\end{aligned}
$$
ція $\gamma \in$ границею зміни кута між двома довільно обраними відрізками в тілі при прикладенні навантаження, коли довжини цих відрізків прямують до нуля [12] й може бути записана у вигляді:

$$
\begin{aligned}
& \gamma_{x y}=\frac{\partial U_{x}}{\partial y}+\frac{\partial U_{y}}{\partial x} ; \\
& \gamma_{y z}=\frac{\partial U_{y}}{\partial z}+\frac{\partial U_{z}}{\partial y} ; \\
& \gamma_{x z}=\frac{\partial U_{x}}{\partial z}+\frac{\partial U_{z}}{\partial x}
\end{aligned}
$$

де $\vec{U}$ - компоненти вектора переміщень для усіх точок тіла.

В процесі дискретних перегинань корінцевої клейової полімерної пластини (рис. 1) в околі точок a, b, c, o, d, e, f...i (рис. 2, a), що знаходяться на вершинах клиновидних припливів клею, орієнтованих між зошитами послідовної нумерації, можливо спостерігати процес кутового зсуву пластини та зміни геометричних розмірів її півкруглих ділянок, утворених півкруглими фальцями корінцевої частини зошитів:

- перегинання пластини в околі точки а на кут $\alpha_{1}$ призводить до деформації 1-ої ділянки і зміни її геометричних розмірів на $\Delta_{1}$;

$$
\gamma_{(\Delta 1) x y}=\frac{\partial U_{(\Delta 1) x}}{\partial y}+\frac{\partial U_{(\Delta 1) y}}{\partial x} ;
$$


$\gamma_{(\Delta 1) \mathrm{yz}}=\frac{\partial \mathrm{U}_{(\Delta 1) \mathrm{y}}}{\partial \mathrm{z}}+\frac{\partial \mathrm{U}_{(\Delta 1) \mathrm{z}}}{\partial \mathrm{y}}$;

$\gamma_{(\Delta 1) \times z}=\frac{\partial U_{(\Delta 1) x}}{\partial z}+\frac{\partial U_{(\Delta 1) z}}{\partial x}$;

- перегинання пластини в околі точки b на кут $\alpha_{2}$ призводить до деформації 2-ої ділянки та зміни її геометричних розмірів на $\Delta_{2}+\Delta_{2+1}$;

$$
\begin{aligned}
& \gamma_{(\Delta 2+\Delta(2+1) x y}=\frac{\partial U_{(\Delta 2+\Delta(2+1) x}}{\partial y}+ \\
& +\frac{\partial U_{(\Delta 2+\Delta(2+1) y}}{\partial x}
\end{aligned}
$$$$
\gamma_{(\Delta 2+\Delta(2+1) y z}=\frac{\partial U_{(\Delta 2+\Delta(2+1) y}}{\partial z}+
$$$$
+\frac{\partial \mathbf{U}_{(\Delta 2+\Delta(2+1)) z}}{\partial y}
$$$$
\gamma_{(\Delta 2+\Delta(2+1) x z}=\frac{\partial U_{(\Delta 2+\Delta(2+1) x}}{\partial z}+
$$$$
+\frac{\partial U_{(\Delta 2+\Delta(2+1) z}}{\partial x}
$$

- перегинання пластини в околі точки с на кут $\alpha_{3}$ призводить до деформації 3-ої ділянки й зміни її геометричних розмірів на $\Delta_{3}+\Delta_{3+1}$;

$$
\begin{aligned}
& \gamma_{(\Delta 3+\Delta(3+1) x y}=\frac{\partial U_{(\Delta 3+\Delta(3+1) x}}{\partial y}+ \\
& +\frac{\partial U_{(\Delta 3+\Delta(3+1) y}}{\partial x} ; \\
& \gamma_{(\Delta 3+\Delta(3+1) y z}=\frac{\partial U_{(\Delta 3+\Delta(3+1) y}}{\partial z}+ \\
& +\frac{\partial U_{(\Delta 3+\Delta(3+1)) z}}{\partial y} ;
\end{aligned}
$$

$$
\begin{aligned}
& \gamma_{(\Delta 3+\Delta(3+1) x z}=\frac{\partial U_{(\Delta 3+\Delta(3+1) x}}{\partial z}+ \\
& +\frac{\partial U_{(\Delta 3+\Delta(3+1) z}}{\partial x} ;
\end{aligned}
$$

- перегинання пластини в околі точки о на кут $\alpha_{4}$ призводить до деформації 4-ої ділянки й зміни її геометричних розмірів на $\Delta_{4}+\Delta_{4+1}$;

$$
\begin{aligned}
& \gamma_{(\Delta 4+\Delta(4+1) x y}=\frac{\partial U_{(\Delta 4+\Delta(4+1) x}}{\partial y}+ \\
& +\frac{\partial U_{(\Delta 4+\Delta(4+1) y}}{\partial x} ;
\end{aligned}
$$$$
\gamma_{(\Delta 4+\Delta(4+1) y z}=\frac{\partial U_{(\Delta 4+\Delta(4+1) y}}{\partial z}+
$$$$
+\frac{\partial U_{(\Delta 4+\Delta(4+1)) z}}{\partial y}
$$$$
\gamma_{(\Delta 4+\Delta(4+1) x z}=\frac{\partial U_{(\Delta 4+\Delta(4+1) x}}{\partial z}+
$$$$
+\frac{\partial U_{(\Delta 4+\Delta(4+1) z}}{\partial x}
$$

- перегинання пластини в околі точки й на кут $\alpha_{i}$ призводить до деформації і-ої ділянки та зміни їі геометричних розмірів на $\Delta_{\mathrm{i}}$.

$$
\begin{aligned}
& \gamma_{(\Delta i) x y}=\frac{\partial U_{(\Delta i) x}}{\partial y}+\frac{\partial U_{(\Delta i) y}}{\partial x} ; \\
& \gamma_{(\Delta i) x y}=\frac{\partial U_{(\Delta i) x}}{\partial y}+\frac{\partial U_{(\Delta i) y}}{\partial x} ; \\
& \gamma_{(\Delta i) x y}=\frac{\partial U_{(\Delta i) x}}{\partial y}+\frac{\partial U_{(\Delta i) y}}{\partial x} ;
\end{aligned}
$$

Враховуючи негативний вплив дискретних кутових перегинань корінцевих клейових полімерних 
пластин в будь-якій їх частині та неоднорідність тривалості навантажень в процесі експлуатації книжкової продукції призводять до деформації, що утворюється під час перегинань пластини й сприяє пришвидшеному перетворенню процесів пружної деформації на залишкові процеси пластичної деформації.

Застосування клейових композицій високої міцності та високої еластичності, у яких відсутній від'ємний вплив на жорсткість та вигинаючу стійкість склеюваної системи, недоліки кутового зсуву можливо звести до мінімуму, що в свою чергу забезпечить подовжений експлуатаційний період та сприятливий конкурентоспроможний вигляд книжкової продукції.

\section{Висновки}

Величина деформації окремих ділянок корінцевої клейової полімерної пластини, в процесі експлуатаційних навантажень при користуванні книжковими блоками, зшитими нитками, залежить не тільки від пружних властивостей матеріалу клейової композиції, його ізотропності, товщини нанесеного шару, але й від кутів перегинань пластини, які сприяють створенню зон змінної концентрації руйнівних напружень внутрішньої структури.

Напруження виникають на краях з'єднань клейової пластини із папером фальців корінців зошитів з однієї сторони та окантовувальним папером з іншої сторони, у вигляді ділянок стискання та розтягування в місцях дискретних перегинань.

Час дії навантажень, на цих ділянках, пропорційно впливає на зменшення пружних властивостей пластини та розвитку явищ залишкової пластичної деформації.

\section{Список використаної літератури}

1. Палюх О. О. Експериментальне визначення впливу палітурних клеїв на утворення природних кутів розкривання книжкових блоків / О. О. Палюх // Технологія і техніка друкарства. 2018. № 1(59). C. 37-47. DOI: https://doi.org/10.20535/2077-7264.1(59).2018.134755.

2. Гавенко С. Ф. Кинетика пошкодження і руйнування клейових з'єднань при експлуатації / С. Ф. Гавенко // Поліграф. і вид. справа. 2012. № 3. С. 91-96.

3. Гавенко С. Ф. Дослідження факторів впливу на кути розкривання книжкових блоків / С. Ф. Гавенко, І. Ю. Логазяк, Л. В. Туряб // Технологія і техніка друкарства. 2012. № 1(35). С. 67-73. Режим доступу: http://ttdruk.vpi.kpi.ua/article/view/32593.

4. Гавенко С. Ф. Технологія позошитного скріплення нитками книжкових блоків / С. Ф. Гавенко, І. Ю. Логозяк. Львів: УАД, 2012. 168 с.

5. Гавенко С. Ф. Технологія та обладнання для мікрохвильового висушування книжкових блоків / С. Ф. Гавенко, Г. М. Йордан. Львів: УАД, 2012. $144 \mathrm{c}$.

6. Гавенко С. Ф. Технологія окантовування корінців книжкових блоків / С. Ф. Гавенко, Л. Й. Кулик, Г. М. Йордан. Львів: УАД. 2018. 92 с.

7. Петриашвили Г. Г. Влияние угла раскрытия книжного блока на результат оценки прочности клеевого соединения методом pull test / Г. Г. Петриашвили // Квалілогія книги: зб. наук. пр. Львів: УАД, 2007. Вип. 2. С. 89-93. 
8. Петриашвили Г. Г. Математическая модель напряженно-деформированного состояния клеевого соединения книжного блока / Г. Г. Петриашвили // Поліграфія і видавнича справа: зб. наук. пр. Л.: УАД, 2007. Вип. 1(45). С. 181-185.

9. Кулик Л. Й. Удосконалення технології окантовування корінців книжкових блоків при незшивному клейовому скріпленні: автореф. дис... канд.техн.наук. Львів: УАД. 2002. 24 с.

10. Воробьев Д. В. Технология послепечатных процессов / Д. В. Воробьев. М.: МГУП. 2007. 393 с.

11. Лазаренко Е. Т. Поліграфічні матеріали / Ю. Ц. Жидецький, Е. Т. Лазаренко, Н. Д. Лотошинська. Львів: Афіша. 2000.

12. Кутовий Л. В. Опір матеріалів / Л. В. Кутовий, Т. П. Зінченко, В. А. Овчаренко. Краматорськ. 2007. Ч. 1. ДДМА. 196 с.

\section{References}

1. Paliukh, O. O. (2018). Eksperymentalne vyznachennia vplyvu paliturnykh kleiv na utvorennia pryrodnykh kutiv rozkryvannia knyzhkovykh blokiv. Journal of Tekhnolohiia i tekhnika drukarstva, 1(59), 37-47. DOI: https://doi.org/10.20535/2077-7264.1(59).2018.134755 [in Ukrainian].

2. Havenko, S. F. (2012). Kynetyka poshkodzhennia i ruinuvannia kleiovykh z'iednan pry ekspluatatsii. Journal of Polihraf. i vyd. sprava, 3, 91-96 [in Ukrainian].

3. Havenko, S. F. \& Lohaziak, I. Yu. \& Turiab, L. V. (2012). Doslidzhennia faktoriv vplyvu na kuty rozkryvannia knyzhkovykh blokiv. Journal of Tekhnolohiia $i$ tekhnika drukarstva, 1(35), 67-73. Retrieved from http://ttdruk.vpi.kpi.ua/article/view/32593 [in Ukrainian].

4. Havenko, S. F. \& Lohoziak, I. Yu. (2012). Tekhnolohiia pozoshytnoho skriplennia nytkamy knyzhkovykh blokiv. Lviv: UAD, 168 p. [in Ukrainian].

5. Havenko, S. F. \& Yordan, H. M. (2012). Tekhnolohiia ta obladnannia dlia mikrokhvylovoho vysushuvannia knyzhkovykh blokiv. Lviv: UAD, 144 p. [in Ukrainian].

6. Havenko, S. F. \& Kulyk, L. Y. \& Yordan, H. M. (2018). Tekhnolohiia okantovuvannia korintsiv knyzhkovykh blokiv. Lviv: UAD, 92 p. [in Ukrainian].

7. Petriashvili, G. G. (2007). Vliyanie ugla raskrytiya knizhnogo bloka na rezul'tat otsenki prochnosti kleevogo soedineniya metodom pull test. Journal of Kvalilohiia knyh, 2, 89-93. Lviv: UAD [in Ukrainian].

8. Petriashvili, G. G. (2007). Matematicheskaya model' napryazhennodeformirovannogo sostoyaniya kleevogo soedineniya knizhnogo bloka. Journal of Polihrafiia i vydavnycha sprava, 1(45), 181-185. Lviv: UAD [in Ukrainian].

9. Kulyk, L. Y. (2002). Udoskonalennia tekhnolohii okantovuvannia korintsiv knyzhkovykh blokiv pry nezshyvnomu kleiovomu skriplenni. Lviv: UAD, 24 p. [in Ukrainian].

10. Vorob'ev, D. V. (2007). Tekhnologiya poslepechatnykh protsessov. Moscow: MGUP, 393 p. [in Russian].

11. Zhydetskyi, Yu. Ts. \& Lazarenko, E. T. \& Lotoshynska, N. D. (2000). Polihrafichni materialy. Lviv: Afisha [in Ukrainian].

12. Kutovyi, L. V. \& Zinchenko, T. P. \& Ovcharenko, V. A. (2007). Opir materialiv. Kramatorsk: DDMA, chapter 2, 196 p. [in Ukrainian].

\footnotetext{
Величина деформации отдельных участков корешковой клеевой полимерной пластины в процессе эксплуатационных нагрузок при пользовании книжными блоками,
} 


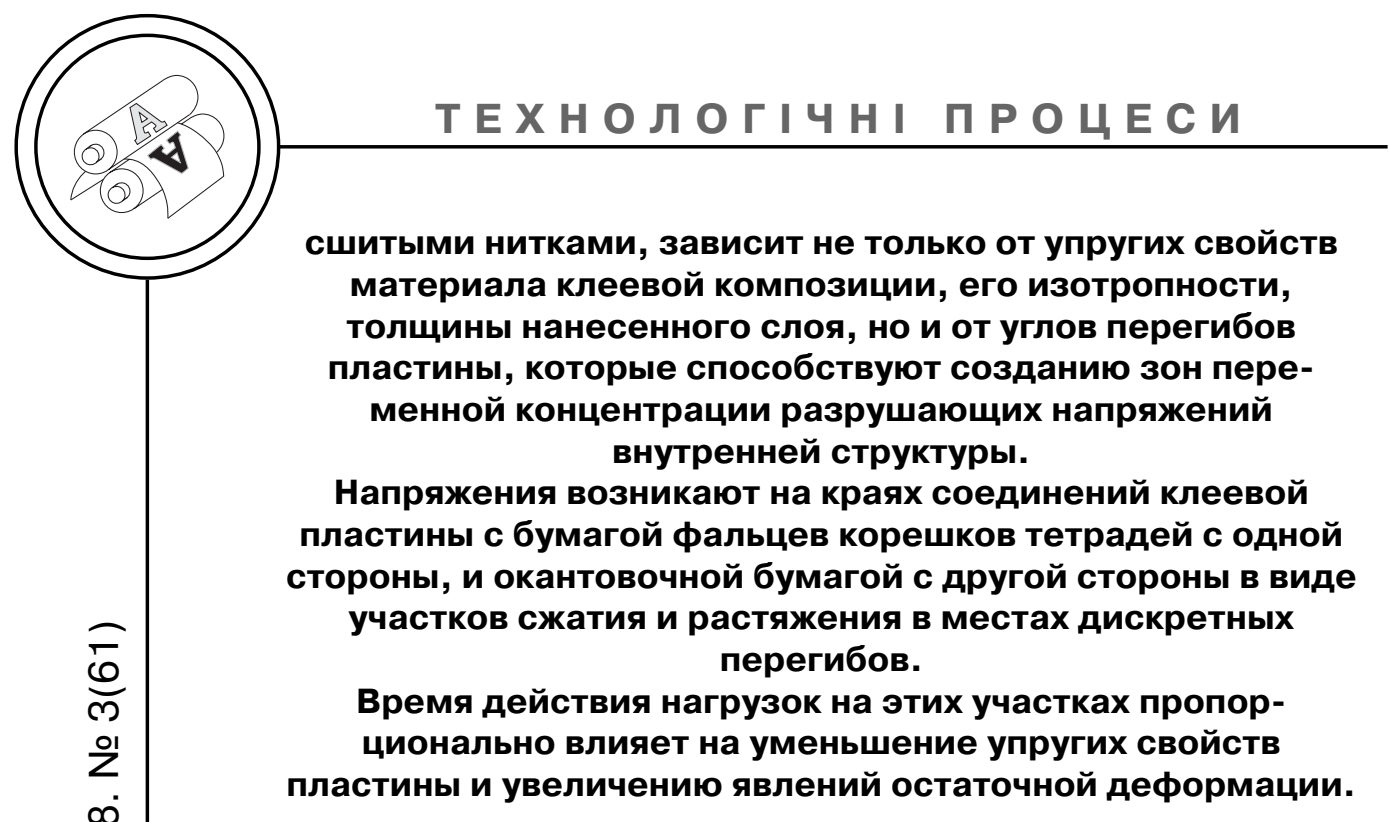

Ключевые слова: корешок блока; перегиб пластины; клеевая композиция; полимерная пластина; раскрывание блока; усилия растяжения; угловое смещение.

The amount of deformation of individual sections of a radial adhesive polymer plate, during operational loads when using book blocks stitched together, depends not only on the elastic material properties of the adhesive composition, its isotropy,

the thickness of the applied layer, but also on the angles of the plate kinks that contribute to creating variable zones concentration of destructive stresses of the internal structure. Taking into account the negative influence of discrete angular bends of rooted glue polymeric plates in any part of it and the heterogeneity of the duration of loads during the exploitation of book products lead to deformation formed during bending of the plate and promotes the accelerated transformation of processes of elastic deformation into residual processes of plastic deformation.

The use of high strength and high elastic adhesive compositions, which do not have a negative effect on the stiffness and bending stability of the glued system, can minimize the disadvantages of the angular displacement, which in turn will provide a prolonged operating period and a favorable competitive appearance of book products.

Keywords: root of the block; plate bending; adhesive composition; polymer plate; block opening; stretching force; angular displacement. 